\title{
SOMATOFORM DISORDERS - A PEDIATRIC EXPERIENCE
}

\author{
Nada Pop-Jordanova ${ }^{1}$, Tatjana Zorcec ${ }^{2}$ \\ ${ }^{1}$ Macedonian Academy of Sciences and Arts, Skopje, R. Macedonia \\ ${ }^{2}$ University Pediatric Clinic, Skopje, R. Macedonia
}

Corresponding Author: Prof. Nada Pop-Jordanova, Macedonian Academy of Sciences and Arts, Bul. Krste Misirkov 2, 1000 Skopje, R. Macedonia; e-mail: popjordanova.nadica@gmail.com

\begin{abstract}
Somatization in children consists of the persistent experience and complaints of somatic distress that cannot be fully explained by a medical diagnosis.

Working at the Psychophysiological Department at the University Clinic we are dealing with more than 100 children per year manifesting this kind of disorders.

The aim of this article is to summarize some specific characteristics of the somatoform disorder in a group of 243 children, mean age $10.31( \pm 2.75)$ years for both genders, selected randomly. The used psychometric instruments are: CBCL, EPQ for children, and MMPI-201 for mothers.

The obtained results showed high scores for somatization, extroversion and accentuated anxiety for children; as well as a typical Hs-Hy personality profile for mothers.

The treatment with cognitive-behavior therapy and biofeedback showed very positive outcome.
\end{abstract}

Keywords: somatoform disorders, children, biofeedback, psychology

\section{Introduction}

Somatoform disorders are a group of psychological disorders in which a patient experiences physical symptoms that are inconsistent with or cannot be fully explained by any underlying general medical or neurologic condition. This entity is common in pediatric population. It is assumed that more than $50 \%$ of patients in a pediatric settings belong to this group. In a general population the somatoform disorders are present in $11 \%$ of girls and $4 \%$ of boys [1].

This group of disorders can be represented by a wide spectrum of severity, ranging from mild self-limited symptoms, such as stomachache and headache, to chronic disabling symptoms, such as seizures and paralysis. It can be said that the somatoform disorders represent the serious end of a continuum of somatic symptoms [2-5].

It is important to note that these symptoms are not intentionally produced or under voluntary control.
Somatization can be associated temporarily with psychosocial stress and persist even after the acute stressor has been resolved, resulting in the belief by the child and his/her family that the correct medical diagnosis has not yet been found. Thus, patients and families may continue to seek repeated medical treatment after being informed that no acute physical illness has been found and that the symptoms cannot be fully explained by a general medical condition. For the economical point of view, it produces unnecessary expenses in the health care system with heavy utilization of resources through repeated hospitalizations, consultations from different specialists, and ineffective investigations and treatments.

Somatoform disorders are additionally associated with poor school performance and attendance and overall impaired functioning [6-9].

The Diagnostic and Statistical Manual of Mental Disorders, Fourth Edition (DSM-IV) 
classifies somatoform disorders in the following diagnoses: somatization disorder, undifferentiated somatoform disorder, somatoform disorder not otherwise specified (NOS), conversion disorder, pain disorder,body dysmorphic disorder, and hypochondriasis. The diagnostic criteria for the somatoform disorders were established for adults and are applied to children for lack of child-specific research base and a developmentally appropriate alternative system $[10,11]$.

The following criteria are required for a diagnosis of somatoform disorders:

- Four different pain sites (e.g., head, abdomen, back, joints, extremities, chest, rectum) or painful functions (e.g., menstruation, sexual intercourse, urination)

- Two gastrointestinal symptoms other than pain (e.g., nausea, bloating, vomiting, or intolerance of several different foods)

- One sexual or reproductive symptom other than pain (e.g., erectile or ejaculatory dysfunction, irregular menses, excessive menstrual bleeding)

- One pseudoneurological symptom (e.g., impaired balance, paralysis, aphonia, urinary retention)

The so-called "normal" childhood includes an extraordinary range of experiences and adaptive responses. Nevertheless, acute and chronic situations which arise could exceed a child's ability to restore equilibrium. If sufficiently intense or prolonged, these conditions can evoke a variety of biologic and behavior responses. Such responses can lead to the development of a diagnosable disorder. When life is disrupted, often insidiously, worry, sadness, or other unpleasant thoughts and emotions can ensue, along with physical distress presenting as a myriad of bodily symptoms. This is true for both, adults and children [12-15].

It is known that response to different forms of stress is highly individual. One child might have the resilience to move through a difficult life circumstance that overwhelms another, so no single predictable sign or symptom points to the psychosomatic origin of a physical complaint. Table 1 shows the most common pediatric somatic complains related to the age of appearance.
Table 1

Most common somatoform complains in children

\begin{tabular}{|l|l|}
\hline Symptom & Age of appearance \\
\hline Recurrent abdominal pain & Preschools children \\
\hline Headache & Schoolers \\
\hline Muscle pains & Puberty \\
\hline Fatigue & Puberty \\
\hline Neurological symptoms & Puberty \\
\hline
\end{tabular}

Recurrent complaints often present as diagnostic and treatment dilemmas to the primary care practitioner or a family doctor who is trying to make sense of these symptoms. The doctors may feel poorly prepared and/or may have little time to assess or treat the somatic concerns. While the more disabling somatic complaints are more likely to be referred to a mental health professional, youngsters presenting with these disabling physical symptoms bridge both medical and psychological domains and present a puzzling quandary for professionals from either field if working with them alone. The nature of these symptoms requires an integrated medical and psychiatric treatment approach to successfully decrease the impairment caused by these disorders [16, 17].

The aim of this article is to summarize some psychological specifics of children with somatoform disorders as well to correlate this traits with mother's personality.

\section{Sample and methodology}

In this article we evaluate 243 patients with somatoform complains randomly selected from patients treated at the Department for Psychophysiology at the University Pediatric Clinic in Skopje, during a period of 5 years. The mean age of the patients was $10.31( \pm 2.75)$ years for both genders.

The Department for Psychophysiology deals with over 1000 outpatient/year, inpatients comprising 80-100 patients/year, mainly children with somatoform disorders, eating disorders, behavior problems, ADHD, autism, OCD, anxiety disorders etc.

For the evaluated group of patients we applied interviews for mothers and children, Child Behavior Checklist (CBCL) for children 
below 12 years, Eysenck Personality Questionnaire (EPQ) for children over 10 years, and Minnesota Multiphase Personality Inventory (MMPI-201) for mothers.

CBCL [18] is designed to obtain the parent's descriptions of their own child behavior in a standardized format. There are 118 behavior problem items plus spaces for parents to write and score additional physical problems with no known medical cause. Two broadband grouping are focused: internalized and externalized. They reflect a distinction between fearful, inhibited, over controlled behavior and aggressive, antisocial, under controlled behavior. The profile can contribute to a formal diagnosis by showing the degree of child's deviance in behaviors that parents are more likely to observe than clinicians, as well as help to structure effective training.

EPQ [19] evaluates the four classical characteristics of the personality: $\mathrm{N}$ (level of emotional stability/neurosis); $\mathrm{E}$ (dimension of extraversion/introversion); P (psychotic behavior/psychopathy) and L (degree of dissimulation or social adaptability). Our previous experience with this psychometric test confirmed the validity, reliability and discriminability of the obtained results, especially in preadolescents (10-12 years) [20].

MMPI-201 [21] contains ten clinical scales: Scale 1 - Hypochondriasis scale which measures a person's perception and preoccupation with their health and health issues; Scale 2 the Depression scale measures a person's depressive symptoms level; Scale 3 - the Hysteria scale measures the emotionality of a person; Scale 4 - the Psychopathic Deviate scale measures a person's need for control or their rebellion against control; Scale $5-$ Paranoia scale measures a person's inability to trust; Scale 6 - the Psychasthenia scale measures a person's anxiety levels and tendencies for somatization and obsession; Scale 7 - the Schizophrenia scale measures a person's unusual/odd cognitive, perceptual, and emotional experiences, and Scale 10 - the Mania scale measures a person's energy, euphoria or hyperactivity.

Three scales L, F and $\mathrm{K}$ are validity scales and measure the readiness of the responders to this kind of examination. L scale refers to rigidity or naiveté of responder's approach to the test material; $F$ scale refers to confused thinking/ lack of understanding the questions or malingering; $\mathrm{K}$ scale refers to responses chosen to be socially acceptable.

Raw scores on the scales are transformed into a standardized metric known as T-scores (Mean or Average equals 50, Standard_Deviation equals 10), making interpretation easier for clinicians. Before the analysis of the clinical scales, some criteria should be satisfied: $\mathrm{L}$ and $\mathrm{K}$ scales must be with the score $\leq 70$ and $\mathrm{F}$ scale $\leq 80$. A significant advantage of the MMPI over other self-report and observer rating scales is that it provides valid and reliable estimates of response bias.

The obtained results are statistically evaluated using Statistic 10 package.

\section{Results}

The sample comprises 243 children with somatoform disorders, randomly selected. The mean age of the evaluated patients was 10.31 $( \pm 2.75)$ years for both genders. All of them have been outpatients at the Psychophysiology Department of the University Pediatric Clinic in Skopje, the capital of the Republic of Macedonia. The main problems were stomachache 64\%; nausea/vomiting 10\%; abdominal colic $16 \%$ and palpitation/short breathing $5 \%$.

The diagnosis is confirmed using the DMS-IV-R Manuel.

The results obtained for CBCL for boys are presented on Fig. 1. As it can be seen, mothers pointed the internalized symptoms as anxiety and somatoform problems; they are over T-score which is significant. 


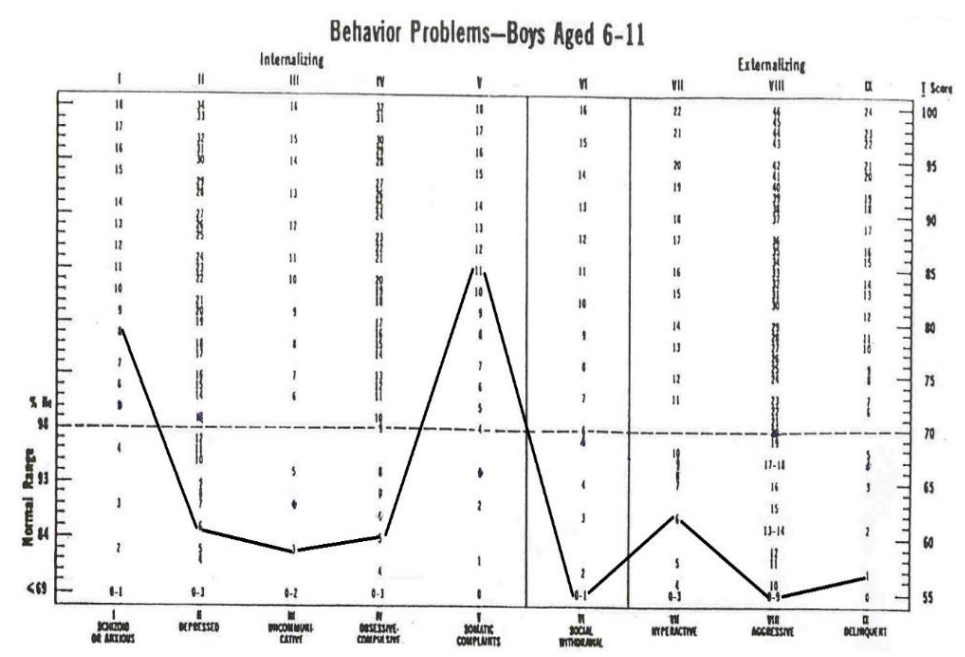

Fig. 1 - Obtained profile for boys on CBCL

For girls, the obtained profile is shown on Fig. 2. Similarly, somatoform complains are dominant and over T-score.

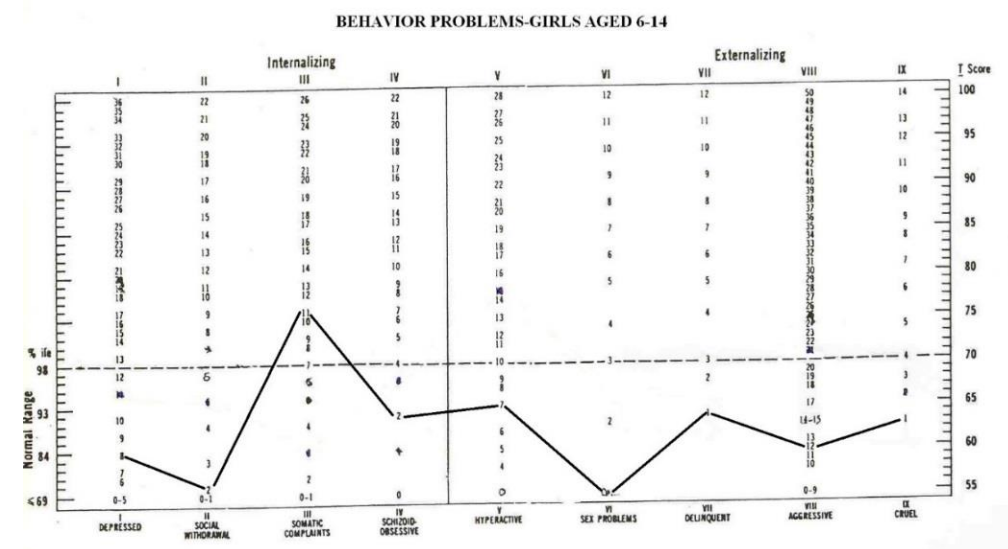

Fig. 2 - Obtained CBCL profile for girls

The EPQ profile for boys (Fig. 3) shows accentuated neurotic tendencies ( $<<0.05$ ), as well as extroversion $(p<0.05)$.

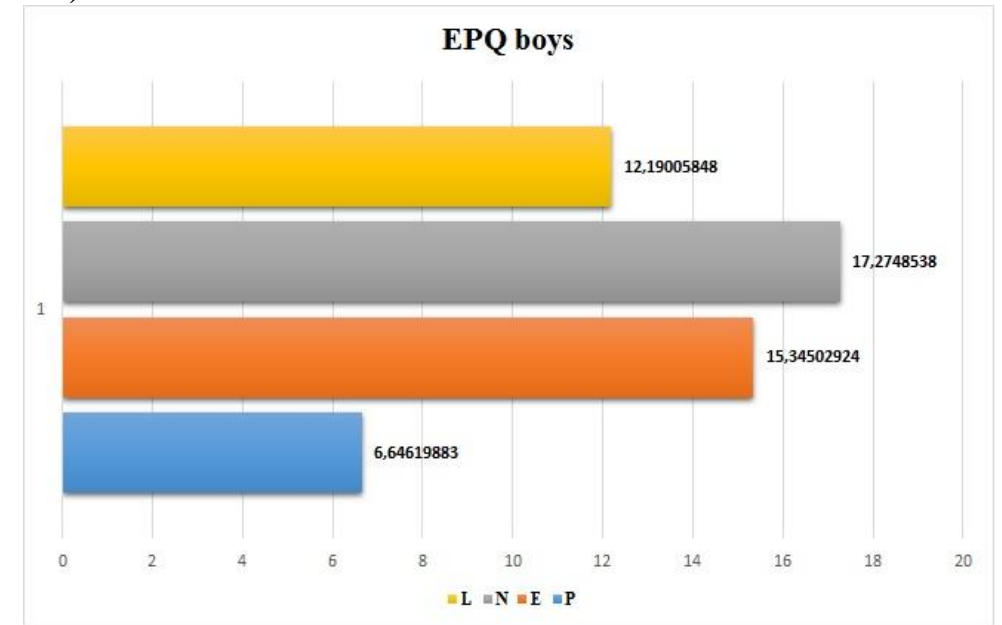

Fig. 3 - EPQ results for boys 
For girls (Fig. 4) the EPQ results confirm the much accentuated extroversion (p < 0.05), while other personality traits are in normal values.

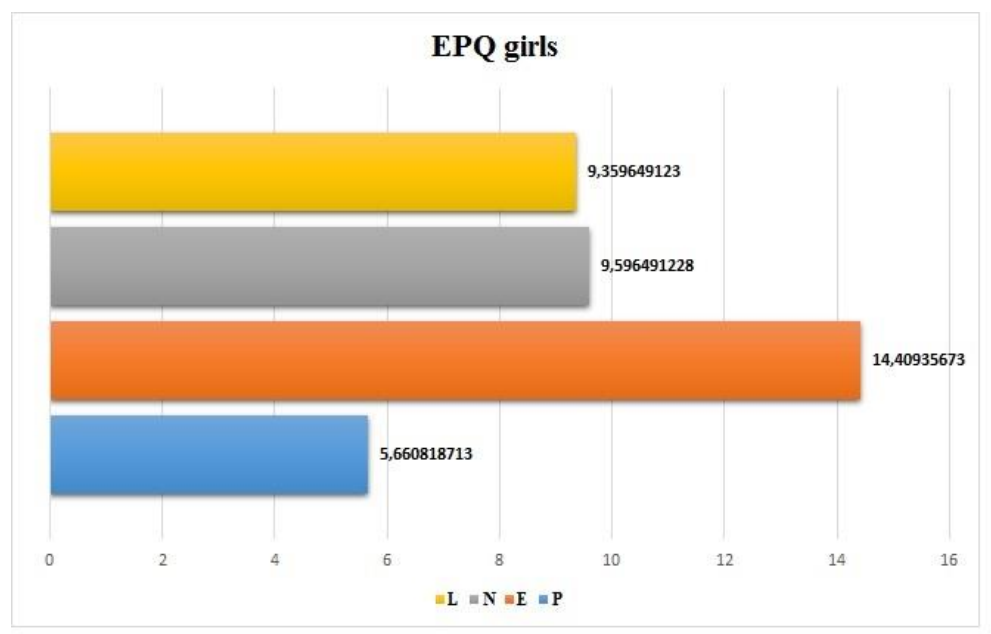

Fig. 4 - EPQ results for girls

The EPQ results are compared with the control group of healthy children at the same age $(\mathrm{N}=25)$.

Having in mind that mothers are the most important personalities for child development, we tested mothers with MMPI-201. The obtained group profile is shown on Fig. 5. The ty- pical Hs-Hy profile confirms that mothers of these children are hypersensitive, anxious and react similarly as their children with somatization. The influence of this type of mother as a model for children's behavior is very important not only for the diagnostics but also for the treatment strategies.

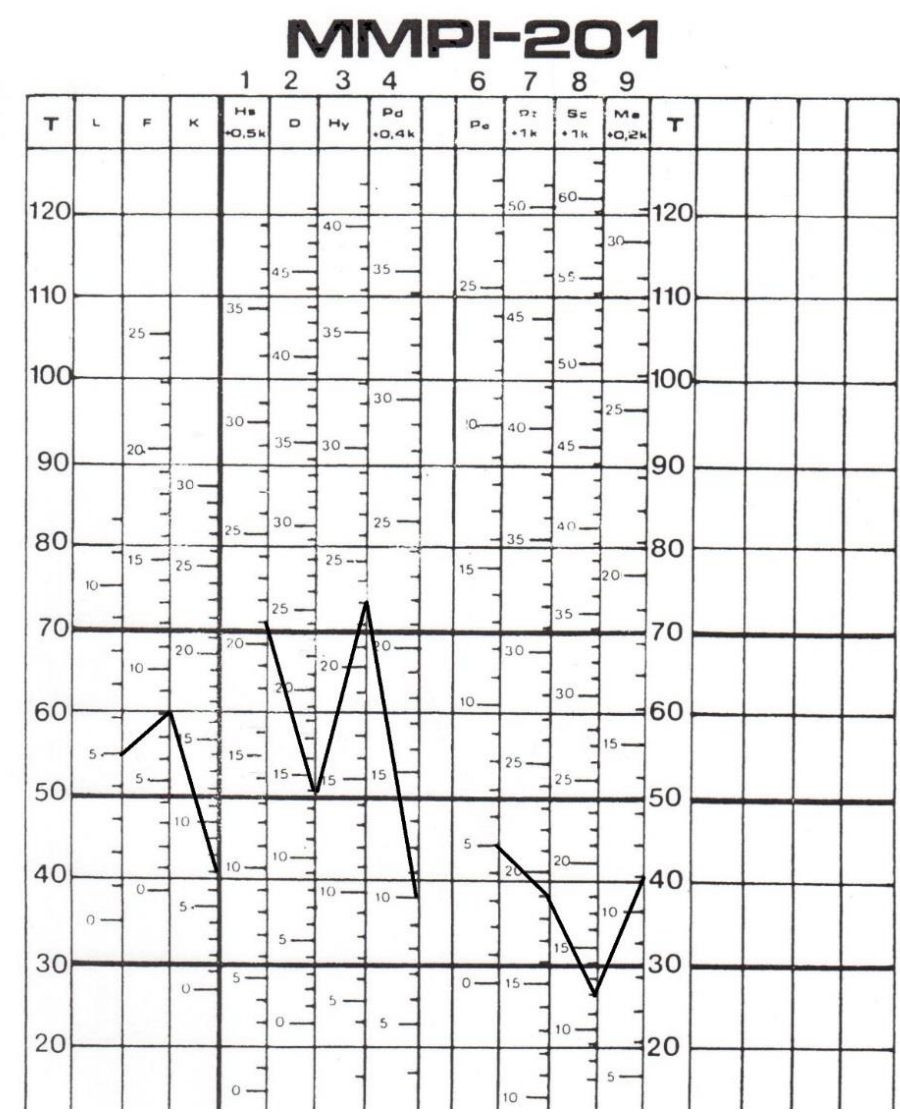

Fig. 5 - Obtained MMPI-201 profile for mothers 
The treatment strategies we used are: cognitive-behavioral therapy, family therapy, and peripheral and neurofeedback therapy. As biofeedback modalities we applied electro dermal response (skin conductance) training comprising 10 sessions, organized one a week. Concerning

E D R

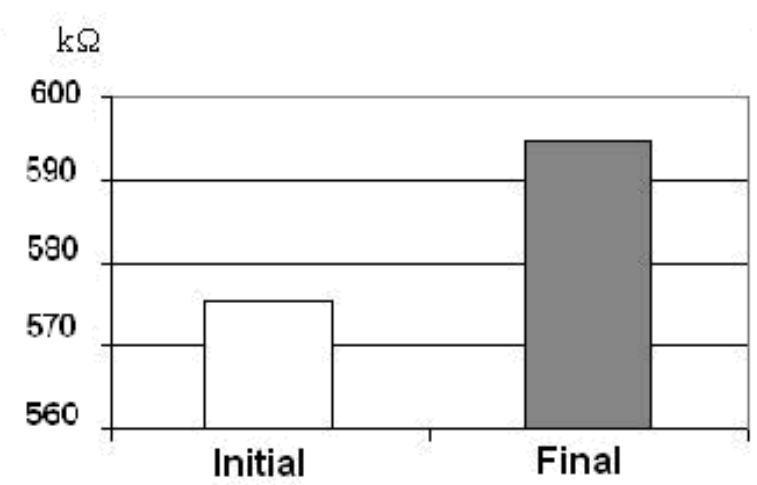

neurofeedback, we used also 10 session of SMR training in $\mathrm{Cz}$ positions. SMR means somatosensory rhythm (12-15 Hz.) which is needed for calming the patient and to produce better cognitive abilities. The obtained results for biofeedback are very satisfactory (Fig. 6 and Fig 7).

Fig. 6 - Results for EDR and SMR training

The calculated $\boldsymbol{t}$-test $10.05(\mathbf{p}<\mathbf{0 . 0 1})^{* *}$ for both biofeedback results shows significant improvement.

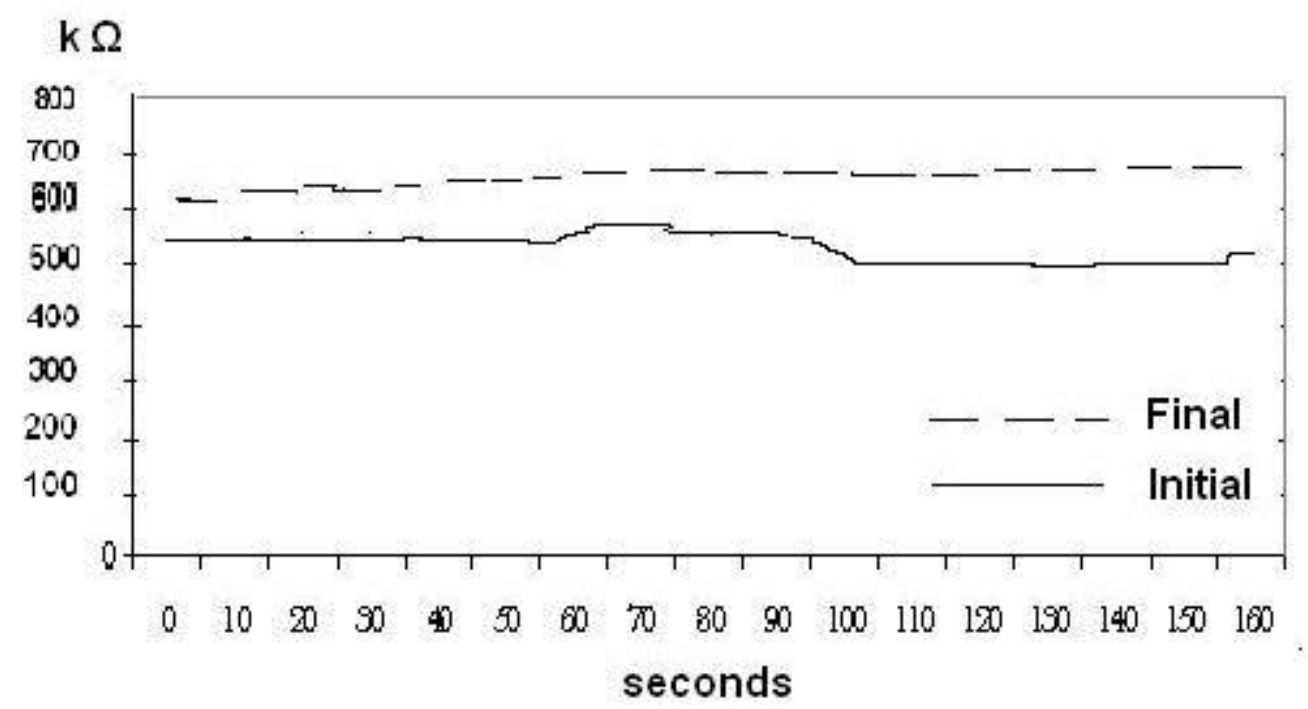

Fig. 7 - Changes for electro dermal activity in initial and final biofeedback session

We have a previously positive experience with the biofeedback therapy [22].

\section{Discussion and conclusion}

Being a puzzle between somatic and psychological illness, somatoform disorders can be comorbid with anxiety disorders (separation anxiety, posttraumatic stress disorder) or depression. In this context, psychological/psychiatric interventions are needed [23-29].
It is confirmed that somatoform disorders follow a developmental sequence in which young person experience some affective distress and react in some form of somatic sensations [3032]. When the child is younger, the most dominant symptoms are recurrent abdominal pain, but later headache, neurological symp- 
toms, fatigues, and sleep problems emerge. The difficulty expressing emotional distress verbally is widely thought to underlie the presentation of physical symptoms that cannot be explained in medical terms.

In an early childhood the male to female ration of the somatoform disorders is practically equal, but in adolescence, girls report nearly twice more symptoms than boys.

Krishnakumar and colleagues [30] believe that having more negative affect, being more sensitive to change in the environment, and not persisting in the completion of tasks elevates the risk of developing a conversion disorder in childhood. In addition to using ineffective coping strategies, children with recurrent somatic symptoms tend to focus more intently on the bodily sensations and have heightened emotional responses to stress.

Stuart and Noyes [33] have hypothesized that somatizing behavior is best understood as a unique form of interpersonal behavior driven by an anxious and maladaptive attachment style. Poor coping styles and reinforcement-seeking behavior may also place an individual at risk for developing a somatoform disorder. Youth with more complaints of pain and physical symptoms not only report being angry more often but also use less-effective strategies to cope with their anger.

Some evidence suggests that medically unexplained symptoms are related to the prior experience of illness in the family and previous unexplained symptoms in the individual. This may reflect a learned process whereby illness experiences lead to symptom monitoring. In this context, the personality profile of mothers could serve as a model for manifestation of symptoms [31-36].

As conclusion we can say that the somatoform disorders in childhood represent a common diagnostic issues. The pediatrician must be aware of the psychological basis of the etiology. A multidisciplinary approach (pediatricians, psychiatrist, and psychologist) is needed.

As therapeutic strategies, the cognitivebehavior therapy, and especially the biofeedback modalities (electro dermal response and neurofeedback) are very useful.

\section{REFERENCES}

1. Fritz KG, Fritsch S, Hagino O. Somatoform disorder in children and adolescents: a review in the past 10 years. J Am Acad Child Adolesc Psychiatry. 1997; 36: 1329-1337.

2. Pop-Jordanova N. Somatoformni rastrojstva, Misla, 2010.

3. Pop-Jordanova N. Pedijatriska psihofiziologija, Misla, 2001.

4. Garralda ME. Unexplained physical complaints. Child Adolesc Psychiatr Clin N Am. 2010 Apr; 19(2): 199209.

5. Maj M, Akiskal HS, Mezzich JE, Okasha A. Somatoform Disorders, Wiley\&Sons Ltd, USA, 2005.

6. Garralda E. Somatization in childhood. The child psychiatrist's concern? CAP Faculty Meeting, RCPsych Manchester, September 2012

7. Shaw RJ, DeMaso DR. Mental Health Consultation with Physically Ill Children and Adolescents. Somatoform Disorders. Clinical Manual of Pediatric Psychosomatic Medicine. Washington, DC: American Psychiatric Publishing; 2006. 8: 143-166.

8. Shaw RJ, Spratt EJ, Bernard RS, DeMaso DR. Somatoform Disorders. Shaw RJ, DeMaso DR eds. Textbook of Pediatric Psychosomatic Medicine: Mental Health Consultation with Physically Ill Children. Washington DC: American Psychiatric Press; 2010. 8: 121-139.

9. Walker LS, Garber J, Smith CA, Van Slyke DA, Claar RL. The relation of daily stressors to somatic and emotional symptoms in children with and without recurrent abdominal pain. J Concul Clin Psychol. 2001, 69 (1): 85-91.

10. Somatoform disorders. In: American Psychiatric Association. Diagnostic and Statistical Manual of Mental Disorders DSM-IV-TR. 4th ed. Text revision. Arlington, VA: American Psychiatric Association; 2000: 485-512.

11. Schulte IE, Petermann F. Somatoform disorders: 30 years of debate about criteria! What about children and adolescents? J Psychosom Res. 2011; 70(3): 218-28.

12. Silber TJ. Somatization disorders: diagnosis, treatment, and prognosis. Pediatr Rev. 2011 Feb; 32(2): 56-63.

13. Jellesma FC, Rieffe C, Terwogt MM, Kneepkens CM. Somatic complaints and health care use in children: Mood, emotion awareness and sense of coherence. Soc Sci Med. 2006 Nov; 63(10): 2640-8.

14. Rieffe C, Terwogt M. Emotion understanding in children with frequent somatic complaints. European Journal of Developmental Psychology. 2004. 1: 31-47.

15. Miers AC, Rieffe C, Meerum Terwogt M, Cowan R, Linden $\mathrm{W}$. The relation between anger coping strategies, anger mood and somatic complaints in children and adolescents. J Abnorm Child Psychol. 2007 Aug; 35(4): 653-64.

16. Kelly C, Molcho M, Doyle P, Gabhainn SN. Psychosomatic symptoms among schoolchildren. Int J Adolesc Med Health. 2010 Apr-Jun; 22(2): 229-35. 
17. Ibeziako P, Bujoreanu S. Approach to psychosomatic illness in adolescents. Curr Opin Pediatr. 2011 Aug. 23(4): 384-9.

18. Achenbach TM. Manual for the child behavior checklist (4-18) and 1991 Profile, Burlington, VT: University of Vermont, Department of Psychiatry, 1991.

19. Eysenck HJ, Eysenck SBJ. Manual of the Eysenck personality questionnaire, London, Holder and Stroughton, 1975.

20. Pop-Jordanova N., Zorcec T. Age, Gender and Disorder Related Personality Characteristics of Pediatric Patients Measured by Eysenck Personality Questionnaire, Acta Informatica Medica, 2009; 18(4): 208-213.

21. Biro M. Praktikum za primenu i interpretaciju MMPI, Savez društava psihologa Srbije, Beograd, 1981.

22. Pop-Jordanova N. Biofeedback application for somatoform disorders and attention deficit hyperactivity disorder (ADHD) in children. Int J Med Sci. 2009; 1(2): 17-22.

23. Dufton LM, Dunn MJ, Compas BE. Anxiety and somatic complaints in children with recurrent abdominal pain and anxiety disorders. J Pediatr Psychol. 2009; 34(2): 176-86.

24. Cruz N, O'Reilly J, Slomine BS, Salorio CF. Emotional and neuropsychological profiles of children with complex regional pain syndrome type-I in an inpatient rehabilitation setting. Clin J Pain. 2011; 27(1): 27-34.

25. Konichezky A, Gothelf D. Somatoform disorders in children and adolescents. Harefuah. 2011; 150(2): 180-4, 203.

26. McCauley E, Carlson GA, Calderon R. The role of somatic complaints in the diagnosis of depression in children and adolescents. J Am Acad Child Adolesc Psychiatry. 1991; 30(4): 631-635.

27. Zwaigenbaum L, Szatmari P, Boyle MH, Offord DR. Highly somatizing young adolescents and the risk of depression. Pediatrics. 1999; 103(6 Pt 1):1203-9.

28. Griffin A, Christie D. Taking the psycho out of psychosomatic: using systemic approaches in a paediatric setting for the treatment of adolescents with unexplained physical symptoms. Clin Child Psychol Psychiatry. 2008 Oct; 13(4): 531-42.

29. Taylor S, Garralda E. The management of somatoform disorder in childhood. Curr Op Psych. 2003; 16: 227-31.

30. Krishnakumar P, Sumesh P, Mathews L. Temperamental traits associated with conversion disorder. Indian Pediatr. 2006; 43(10): 895-9.

31. Brown RJ, Schrag A, Trimble MR. Dissociation, childhood interpersonal trauma, and family functionning in patients with somatization disorder. Am J Psychiatry. 2005; 162(5): 899-905.

32. Roelofs K, Spinhoven P, Sandijck P, Moene FC, Hoogduin KA. The impact of early trauma and recent life-events on symptom severity in patients with conversion disorder. J Nerv Ment Dis. 2005; 193(8): 508-14.

33. Stuart S, Noyes R Jr. Attachment and interpersonal communication in somatization. Psychosomatics. 1999; 40(1): 34-43.

34. Campo JV, Bridge J, Lucas A, et al. Physical and emotional health of mothers of youth with functional abdominal pain. Arch Pediatr Adolesc Med. 2007; 161(2): 131-7.

35. Zeharia A, Mukamel M, Carel C, Weitz R, Danziger Y, Mimouni M. Conversion reaction: management by the paediatrician. Eur J Pediatr. 1999;158(2): 160-164.

36. Mohaparta S, Deo S, Satapathy A, Rath N. Somatoform disorder in children and adolescents, German J Psychiatry. 2014; 17 (1): 19-24.

Резиме

\section{СОМАТОФОРМНИ РАСТРОЈСТВА - ПЕДИЈАТРИСКО ИСКУСТВО}

\section{Нада Поп-Јорданова ${ }^{1}$, Татјана Зорчец ${ }^{2}$}

${ }^{1}$ Македонска академија на науките и уметностите, Скопје, Р. Македонија

${ }^{2}$ Универзитетска клиника за детски болести, Скопје, Р. Македонија

Соматизацијата кај децата се карактеризира со постојано искуство и поплаки за соматски проблеми за кои не може да се најде објаснување преку позната медицинска дијагноза. Работејќи на Одделот за психофизиологија на Клиниката за педијатрија, се справувавме со над 100 деца годишно кои манифестираа вакви проблеми. Целта на овој труд е да се сумираат некои специфични карактеристики на соматоформните растројства во група од 243 деца, средна возраст 10.31 ( \pm 2.75$)$ години кај обата пола, избрани случајно. Користени се психометриските инструменти CBCL, EPQ за децата и MMPI-201 за мајките.

Добиените резултати потврдија високи скорови за соматизација, екстроверзија и анксиозност, додека кај мајките е добиен карактеристичен Hs-Ну профил. Лекувањето со когнитивно-бихевиорална терапија и биофидбек покажа позитивни резултати.

Клучни зборови: соматоформни растројства, биофидбек, деца, психологија 